\title{
Anabolic Androgenic Steroid Use Prevalence, Knowledge, and Practice among Male Athletes in Eastern Province of Saudi Arabia
}

\author{
Huda Hassan Aldarweesh ${ }^{1}$, Alyaa Hassan Alhajjaj ${ }^{1^{*}}$
}

${ }^{1}$ Qatif Central Hospital, SAUDI ARABIA

*Corresponding Author: alhajjajal@yahoo.com

Citation: Aldarweesh HH, AlHajjaj AH. Anabolic Androgenic Steroid Use Prevalence, Knowledge, and Practice among Male Athletes in Eastern Province of Saudi Arabia. Electron J Gen Med. 2020;17(2):em187. https://doi.org/10.29333/ejgm/7617

\section{ARTICLE INFO}

Received: 25 Oct. 2019

Accepted: 30 Dec. 2019

\begin{abstract}
Background: Anabolic androgenic steroids (AAS) are synthetic testosterone like hormones. AAS usage by athletes has increased dramatically over the past decade.

Material and Methods: This study was designed to examine the prevalence, attitude and awareness of AAS abuse among athletes $\mathrm{n}$ the Eastern province of Saud Arabia. This was a cross-sectional survey that was conducted among male athletes attending twenty fitness centres in the Eastern Province. It was done during the period from April to August, 2018.

Results: A total of 573 questionnaires were distributed but only 503 participants were included $n$ the final analysis. The frequency of AAS use was $17.69 \%$. The man reason for AAS use was muscle building (68.54\%). The man source of AAS was the coaches. $56.18 \%$ of the users recognize the harmful effects of AAS. The most commonly used oral AAS form was oxandrolone (61.80\%). The most commonly used substance for post cycle therapy was Tamoxifen citrate $n 67.42 \%$ of the users.

Conclusions: $17.69 \%$ of the participants use AAS. Coaches were the man source for AAS. In our study, around half of the gym users have inadequate knowledge about AAS and ts harmful effects. More regulation laws and educational programs are needed.
\end{abstract}

Keywords: AAS, Saudi, testosterone, anabolic steroids

\section{INTRODUCTION}

Performance-enhancing drugs (PED) usage dating back to 776 BC when it was used by Greek and Roman athletes. They used mixtures of wine, herbs along with special plants to win their sports. Different plants were used because of their analgesic effect and enhancing endurance. The first time to use male hormones was in the 1950s by the Soviet Olympic team $(1,2)$.

Anabolic steroids are synthetic substances with testosterone like hormones, but with longer physiological effects in the body. The appropriate term for these compounds is anabolic-androgenic steroids (AAS). "Anabolic" is the dominant action which means building up muscles, while "androgenic" related to sex male characteristics (3). AAS are commonly prescribed for the treatment of male hypogonadism and other conditions that are associated with muscle wasting such as cancer, HIV, malnutrition, renal and hepatic failure (4).

Currently, athletes and others use AAS in supraphysiological doses to boost their performance and to build their muscles. AAS can be taken as oral or intramuscular injection $(5,6)$.

The most commonly used AAS are: Testosterone, Metandienone, Stanazolol, Oxandrolone and others.
Steroids are often used in patterns to lessen the unwanted reactions, or for better anabolic effect. One of these patterns is "cycling" which involves taking multiple doses of steroids over a specific period of time, alternating with drugs free periods. Some combine different types of steroids for a greater anabolic effect and this is called "stacking" $(7,8)$.

Many users often use a pyramid administration schedule "pyramiding", gradually increasing doses during the first half of a cycle before decreasing them in the second half $(9,10)$. In spite of different methods used, no scientific evidence that these patterns could reduce the adverse effects.

With the increasing prevalence of AAS usage, many users reported some negative effects such as testicular atrophy (40\%-51\%) with spermatogenic dysfunction, acne vulgaris (40\%-54\%), cutaneous striae (34\%), gynecomastia (10\%-34\%), and injection site pain $(36 \%)(7,11)$.

Also, AAS has some harmful cardiovascular side effects (hypertension, arrhythmia, left ventricular hypertrophy, dyslipidaemia), hepatic effects (peliosis hepatitis, increased transaminases), behavioural effects (mood swings, aggression, and depression) (12-15).

Short term usage of AAS (physiological and supraphysiological doses) proved to be harmless by Recent prospective clinical studies (16-18). 
Table 1. Sociodemographic characteristics and health status of AAS users in comparison with non-users

\begin{tabular}{|c|c|c|c|c|c|c|c|}
\hline \multirow[t]{2}{*}{ Variable } & \multicolumn{2}{|c|}{$\begin{array}{c}\text { Anabolic androgenic } \\
\text { steroid user }\end{array}$} & \multicolumn{2}{|c|}{$\begin{array}{l}\text { Anabolic androgenic } \\
\text { steroid non-user }\end{array}$} & \multicolumn{2}{|c|}{ Total } & \multirow[t]{2}{*}{ P-value } \\
\hline & $\#$ & $\%$ & \# & $\%$ & \# & $\%$ & \\
\hline \multicolumn{8}{|c|}{ Age } \\
\hline $15-25$ years & 10 & 11.24 & 128 & 30.92 & 138 & 27.4 & \multirow{4}{*}{0.052} \\
\hline $26-35$ years & 56 & 62.92 & 186 & 44.93 & 242 & 48.1 & \\
\hline $36-45$ years & 23 & 25.84 & 85 & 20.53 & 108 & 21.5 & \\
\hline$>46$ years & 0 & 0.00 & 15 & 3.62 & 15 & 3 & \\
\hline \multicolumn{8}{|c|}{ Marital status } \\
\hline Single & 26 & 29.21 & 160 & 38.65 & 186 & 37.0 & \multirow{2}{*}{0.095} \\
\hline Married & 63 & 70.79 & 254 & 61.35 & 317 & 63.0 & \\
\hline \multicolumn{8}{|c|}{ Medical status } \\
\hline Unknown & 77 & 86.52 & 370 & 89.37 & 447 & 88.9 & \multirow{6}{*}{0.171} \\
\hline Anemia & 4 & 4.49 & 18 & 4.35 & 22 & 4.4 & \\
\hline Diabetes & 0 & 0.00 & 4 & 0.97 & 4 & 0.8 & \\
\hline GIT or Respiratory problems & 5 & 5.62 & 9 & 2.17 & 14 & 2.8 & \\
\hline Hypertension or Cardiac problems & 2 & 2.25 & 7 & 1.69 & 9 & 1.8 & \\
\hline Neurological or psychiatric problems & 1 & 1.12 & 6 & 1.45 & 7 & 1.4 & \\
\hline \multicolumn{8}{|c|}{ Level of education } \\
\hline Primary school & 2 & 2.25 & 5 & 1.21 & 7 & 1.4 & \multirow{5}{*}{$<0.001^{*}$} \\
\hline Intermediate school & 10 & 11.24 & 5 & 1.21 & 15 & 3.0 & \\
\hline Secondary school & 31 & 34.83 & 117 & 28.26 & 148 & 29.4 & \\
\hline University & 44 & 49.44 & 267 & 64.49 & 311 & 61.8 & \\
\hline High education & 2 & 2.25 & 20 & 4.83 & 22 & 4.4 & \\
\hline \multicolumn{8}{|c|}{ Occupation } \\
\hline Medical field & 7 & 7.87 & 33 & 7.97 & 40 & 8 & \multirow{7}{*}{0.697} \\
\hline Education field & 9 & 10.11 & 54 & 13.04 & 63 & 12.5 & \\
\hline Engineering field & 4 & 4.49 & 39 & 9.42 & 43 & 8.5 & \\
\hline Military field & 8 & 8.99 & 28 & 6.76 & 36 & 7.2 & \\
\hline Private sector field & 51 & 57.30 & 196 & 47.34 & 247 & 49.1 & \\
\hline unemployed & 10 & 11.24 & 62 & 14.98 & 72 & 14.3 & \\
\hline Retired & 0 & 0.00 & 2 & 0.48 & 2 & 0.4 & \\
\hline \multicolumn{8}{|c|}{ Monthly income } \\
\hline 0 & 4 & 4.49 & 33 & 7.97 & 37 & 7.4 & \multirow{6}{*}{0.096} \\
\hline Less than 5000 & 21 & 23.60 & 114 & 27.54 & 135 & 26.8 & \\
\hline $5000-10000$ & 34 & 38.20 & 150 & 36.23 & 184 & 36.6 & \\
\hline$>10000-15000$ & 20 & 22.47 & 87 & 21.01 & 107 & 21.3 & \\
\hline$>15000$ & 10 & 11.24 & 30 & 7.25 & 40 & 8.0 & \\
\hline Total & 89 & 100 & 414 & 100 & 503 & 100 & \\
\hline
\end{tabular}

Considering the recent spread of AAS use among gym users in the eastern province of Saudi Arabia with the purpose of bodybuilding, there is relatively no enough studies regarding the practice of AAS usage in gym centres of the province. We conducted this study to examine the prevalence, knowledge, and attitude toward AAS usage among male athletes in Eastern Province of Saudi Arabia.

\section{METHODS}

This was a cross-sectional survey that was conducted to examine the prevalence, knowledge, practice and attitude toward AAS usage among male gymnasts attending twenty fitness centres in the Eastern Provinces of Saudi Arabia. It was done during the period from April to August, 2018. These fitness centres were located in different areas in the Eastern province including Qatif, Dammam, Saihat, Khobar, Ras Tanura and AlHasa. Self-administered as well as online questionnaires, Arabic language, were distributed among gym attendees. A total of 573 questionnaires were distributed. 515 (89.88\%) were returned completed. Inclusion criteria were being male, Saudi, older than 15 years and attendees of the selected gyms. Exclusion criteria were being non-Saudi, younger than 15 years, and female.
These questionnaires were created after extensive review of the literature regarding AAS usage. The survey consisted from closed ended questions and multiple response answers. It was divided into three parts: sociodemographic data, type and purpose of using the gym, and the final part questions to assess patterns and practice of AAS use. The study was voluntary and all participants were ensured full confidentiality.

Statistical analysis was performed using IBM SPSS version 21. Standard descriptive and analytics statistics were used to analyse the data. Chi-square test was used to test for significant difference and $\mathrm{P}$-value $\leq 0.05$ was considered significant.

\section{RESULTS}

A total of 573 questionnaires were distributed. 515 questionnaires (89.88\%) were returned completed but only 503 participants were included in the final analysis after exclusion of non-Saudi participants $(n=12) .17 .69 \% \quad(n=89)$ of the participants were AAS users.

Table 1 demonstrates sociodemographic data and health status of the analysed sample and were further classified based on current AAS usage. 
Table 2. Description of gym utilization among AAS users in comparison with non-users

\begin{tabular}{|c|c|c|c|c|c|c|c|}
\hline \multirow{2}{*}{ Variable } & \multicolumn{2}{|c|}{ Anabolic androgenic steroid user } & \multicolumn{2}{|c|}{ Anabolic androgenic steroid non-user } & \multicolumn{2}{|c|}{ Total } & \multirow{2}{*}{ P-value } \\
\hline & \# & $\%$ & $\#$ & $\%$ & $\#$ & $\%$ & \\
\hline \multicolumn{8}{|c|}{ Total duration since starting going to gym } \\
\hline$\leq$ One year & 5 & 5.62 & 112 & 27.05 & 117 & 23.26 & \multirow{2}{*}{$0.00^{\star}$} \\
\hline$>$ One year & 84 & 94.38 & 302 & 72.95 & 386 & 76.74 & \\
\hline \multicolumn{8}{|c|}{ Time duration spends in the gym per day } \\
\hline$\leq$ One hour & 35 & 39.33 & 144 & 34.78 & 179 & 35.59 & \multirow{2}{*}{0.511} \\
\hline$>$ One hour & 54 & 60.67 & 270 & 65.22 & 324 & 64.41 & \\
\hline \multicolumn{8}{|c|}{ Days going to gym per week } \\
\hline$\leq 5$ days & 42 & 47.19 & 236 & 57 & 278 & 55.27 & \multirow{2}{*}{0.068} \\
\hline$>5$ days & 47 & 52.81 & 178 & 43 & 225 & 44.73 & \\
\hline \multicolumn{8}{|c|}{ Main reason of going to gym } \\
\hline Muscle building & 69 & 77.53 & 154 & 37.20 & 223 & 44.33 & \multirow{6}{*}{$0.00^{\star}$} \\
\hline Fitness & 15 & 16.85 & 147 & 35.51 & 162 & 32.21 & \\
\hline Weight loss & 2 & 2.25 & 71 & 17.15 & 73 & 14.51 & \\
\hline Entertainment & 2 & 2.25 & 11 & 2.66 & 13 & 2.58 & \\
\hline Others & 1 & 1.12 & 31 & 7.49 & 32 & 6.36 & \\
\hline Total & 89 & 100 & 414 & 100 & 503 & 100 & \\
\hline
\end{tabular}

Table 3. Supplies, vitamins and other drugs usage among Anabolic androgenic steroid users

\begin{tabular}{|c|c|c|c|c|c|c|}
\hline & \multicolumn{2}{|c|}{$\begin{array}{c}\text { Anabolic androgenic steroid user } \\
\text { Total (89) }\end{array}$} & \multicolumn{2}{|c|}{$\begin{array}{c}\text { Anabolic androgenic steroid non-user } \\
\text { Total (414) }\end{array}$} & \multicolumn{2}{|c|}{$\begin{array}{l}\text { Total } \\
(503)\end{array}$} \\
\hline & $\#$ & $\%$ & $\#$ & $\%$ & $\#$ & $\%$ \\
\hline Proteins & 76 & 85.39 & 234 & 56.52 & 310 & 61.63 \\
\hline Vitamins & 58 & 65.17 & 142 & 34.30 & 200 & 39.76 \\
\hline Amino acids & 69 & 77.53 & 267 & 64.49 & 336 & 66.80 \\
\hline Other Hormones & 86 & 96.63 & 395 & 95.41 & 481 & 95.63 \\
\hline
\end{tabular}

\section{Description of Gym Utilization among AAS Users in Comparison with Non-Users}

The age of the study participants ranging from 15 to more than 45 years. $48.1 \%(n=242)$ of the participants in the age group (26-35) years followed by age group (15-25) years $27.4 \%$ $(n=138) .62 .92 \%(n=56)$ of the AAS users were in this age group (26-35) years.

Married participants constituted the majority of the sample (63\%), but the frequency of AAS use between married participants was around $20 \%$ in comparison to single participants (around 14\%) which was not statistically significant $(\mathrm{P}=0.095)$.

Majority of the Participants $66.2 \%(n=333)$ had either university degree or higher education. Forty-six participants $(13.8 \%)$ of this education level group use AAS and this percentage is lower than users in the lower education level and it was statistically significant $(p<0.001)$.

Almost half of the studied population, $49.1 \%(n=247)$ work in private sectors, while $14.3 \%$ were unemployed. Although our study showed $57.3 \%$ of AAS users were working in the private sector, it does not show statistical significance ( $P=0.697)$. Vast majority of the participants $(88.9 \%)$ have no known medical illness. Monthly income category distribution showed 184 subjects (36.6\%) with an average of 5000-1000 Saudi riyals (SR), followed by 135 (26.8\%) whose monthly income was less than $5000 \mathrm{SR}$, and it was not statistically significant $(\mathrm{P}=0.096)$.

\section{Duration and Reason for Using the Gym}

$76.74 \%$ of the participants ( $n=386$ ) admit going to the gym for more than one year. Majority of AAS went to the gym more than one year (94\%) and it was statistically significant $(\mathrm{P}<$ 0.001). Participants going to the gym for five days or less were $278(55.27 \%)$ and total duration spent at gym more than 1 hour was 324 (64.41\%) (Table 2).
Table 4. Description of steroid use among Anabolic androgenic steroid users

\begin{tabular}{|c|c|c|}
\hline & $\#$ & $\%$ \\
\hline \multicolumn{3}{|c|}{ Duration of steroid use } \\
\hline$<$ Six months & 18 & 20.22 \\
\hline Six months - one year & 12 & 13.48 \\
\hline$>$ One year & 59 & 66.29 \\
\hline \multicolumn{3}{|c|}{ Aim of steroid use } \\
\hline To treat medical problems & 3 & 3.37 \\
\hline For muscle building & 61 & 68.54 \\
\hline To participate in contests & 20 & 22.47 \\
\hline Others reason & 5 & 5.62 \\
\hline \multicolumn{3}{|c|}{$\begin{aligned} \text { Forms of steroid use } \\
\end{aligned}$} \\
\hline Tablet & 13 & 14.61 \\
\hline injection & 15 & 16.85 \\
\hline combination & 61 & 68.54 \\
\hline \multicolumn{3}{|c|}{ How to use } \\
\hline Short cycles & 53 & 59.55 \\
\hline Long cycles & 20 & 22.47 \\
\hline random & 16 & 17.98 \\
\hline \multicolumn{3}{|c|}{ Source of steroid } \\
\hline internet & 15 & 16.85 \\
\hline Coach & 49 & 55.06 \\
\hline pharmacy & 8 & 8.99 \\
\hline friends & 6 & 6.74 \\
\hline Others & 11 & 12.36 \\
\hline Total & 89 & 100 \\
\hline
\end{tabular}

People gave different reasons for going to the gym, muscle building was the main reason in $44.33 \%(n=223)$, followed by fitness $32.21 \% \quad(n=162)$ and it was statistically significant $(\mathrm{P}<0.001)$ (Table 2$)$.

\section{Patterns, Attitude, and Practice among Anabolic Androgenic Steroid Users}

Among AAS users, $66.29 \%(n=59)$ used AAS for more than one year. The main reason for AAS use was muscle building (68.54\%) which was statistically significant $(P<0.001)$ (Table 4). 
Table 5. Attitude, knowledge and adverse effects among Anabolic androgenic users

\begin{tabular}{|c|c|c|c|c|}
\hline \multicolumn{5}{|c|}{ Attitude, knowledge and adverse effects $(n=89)$} \\
\hline \multirow{2}{*}{ AAS users $(n=89)$} & \multicolumn{2}{|c|}{ Yes } & \multicolumn{2}{|c|}{ No } \\
\hline & \# & $\%$ & \# & $\%$ \\
\hline Medical examination before starting & 40 & 44.94 & 49 & 55.06 \\
\hline Undergo through post-cycle therapy & 80 & 89.89 & 9 & 10.11 \\
\hline Believe its harmful & 50 & 56.18 & 39 & 43.82 \\
\hline development of complication & 13 & 14.61 & 76 & 85.39 \\
\hline Total & 89 & 100 & 144 & 100 \\
\hline
\end{tabular}

Table 6. Type of AAS use among Anabolic androgenic steroid users

\begin{tabular}{ccc}
\hline Type of steroid use (n=89) & & \\
\hline Oral steroid & $\#$ & $\%$ \\
\hline Anadrol (oxymetholone) & & \\
\hline Anavar (oxandrolone) & 29 & 32.58 \\
\hline Dianabol (methandienone) & 55 & 61.80 \\
\hline Winstrol (stanozolol) & 47 & 52.81 \\
\hline Proviron (mesterolone) & 49 & 55.06 \\
\hline Turinabol (cholorodehydromethyltestosterone) & 34 & 38.20 \\
\hline Injectable steroid & 39.33 \\
\hline Deca-durabolin (nandrolone decanoate) & 40 & 44.94 \\
\hline Sustanon (esterified testosterone) & 40 & 44.94 \\
\hline Primobolam depot (metenolone enanthate) & 45 & 50.56 \\
\hline Others & 21 & 23.60 \\
\hline
\end{tabular}

Table 7. Post cycle therapy among Anabolic androgenic steroid users

\begin{tabular}{ccc}
\hline Post cycle therapy (n=89) & & \\
\hline & $\#$ & $\%$ \\
\hline Tamoxifen citrate (nolvadex) & 60 & 67.42 \\
\hline Clomiphene (clomide) & 44 & 49.44 \\
\hline Anastrozole (arimidex) & 32 & 35.96 \\
\hline Human chorionic gonadotropin-HCG (pregnyl) & 51 & 57.30 \\
\hline Milk thistle (silybum marianum) & 7 & 7.87 \\
\hline Sympathomimetic (clenbuterol) & 31 & 34.83 \\
\hline Others & 24 & 26.97 \\
\hline
\end{tabular}

The main sources of AAS were from the coaches (55.06\%), followed by the internet (16.85\%). Cycling pattern (either long or short cycles) was the most pattern between the Majority of the AAS users (Table 4).

In spite of more than half of AAS users (56.18\%) believe that AAS are harmful, only $44.94 \%$ underwent medical examination before starting AAS. Majority of AAS users $89.89 \%(n=80)$ follow cycling pattern to avoid the complication. $14.61 \%$ admitted developing complications with steroid use though types of complications were not specified in the questionnaires) (Table 5).

Combination (oral and injectable) forms were used by the majority of the AAS users $68.54 \%$ ( $n=61)$.

Majority of the users used different AAS types either in combination or separately. The most commonly used oral AAS form was; Anavar (oxandrolone) (61.80\%), followed by Winstrol (stanozolol) (55.06\%), and Dianabol (methandienone) in $52.81 \%$ of the participants.

While the three most commonly used injectable AAS were Primobolam depot (metenolone enanthate) (50.56\%), followed by Deca-durabolin Sustanon and esterified testosterone equally in $44.94 \%$ of the participants (Table 6).

The most used drug for post cycle therapy was Tamoxifen citrate in $67.42 \%$ of the users $(n=60)$, followed by Human chorionic gonadotropin-HCG (pregnyl) in $57.30 \%$ of the users $(n=51)$.

Almost all AAS users (96.63\%) used also other hormones, followed by proteins $(85.39 \%)$ in addition to AAS (Table 3 ).

\section{DISCUSSION}

This study examined the Prevalence, knowledge and awareness of anabolic androgenic steroids usage among male athletes in the Eastern Province of Saudi Arabia. In this study, the frequency of AAS users was $17.69 \%$ of the participants which is lower that has been reported by similar studies in Saudi Arabia. The frequency of AAS usage was $23.0 \%$ in the eastern province, $54.2 \%$ in the central region (19) and $24.5 \%$ in the western province of Riyadh (20). Our frequency was higher than North region (5.7\%) Western region (14.8\%). The lowest frequency was in the Southern region (2.3\%) (20). A recent cross-sectional survey was carried out among gym users from all the kingdom of Saudi Arabia found the prevalence of AAS use was $9.8 \%$ of the participants (19). Other studies in the Middle East showed a higher prevalence of AAS use for example, Jordan (26\%) (21), followed by Kuwait (22.7\%) (3), and then the UAE (22\%) (22). A possible explanation for this difference in prevalence of AAS use might be due to different reasons such as the sample size and the most likely due the possibility of self-underreporting of AAS use.

In spite of the majority of the AAS users (62.92\%) were in this age group 26-35 years, the age group was not statically significant in relation to the AAS usage and this similar to the UEA study (22).Though other studies like Riyadh, Jordan, and Kuwait, there was a correlation between the age group and AAS use $(3,20,21)$.

Although the majority of participants are married, there was no significant relationship of AAS use to marital status which was similar to the UEA study (22). On the other hand, other studies such as Althobiti study AAS usage was more between married participants (19).

Our results showed that there was a statistically significant inverse relationship between the use of AAS and level of education $(P<0.001)$. This relationship was supported by the UEA study (22) and other studies in Saudi Arabia $(20,23)$. A possible explanation is that men with lower level of education go to the gym to build their muscles and boost their physical appearance rather than health and fitness.

As was reported by other studies, our study showed that the majority of the AAS users were employed $(20,21) .57 .3 \%$ of the AAS users were working in the private sectors but still it didn't show statistical significance $(\mathrm{P}=0.697)$.

Only $56.18 \%$ the AAS users believe that AAS is harmful (though the types of harmful effects were not mentioned) and they insist on using it. No significant difference between AAS 
users and non-users regarding the knowledge of the risks of AAS. Similar to our study, other studies showed that the AAS users had inadequate knowledge about AAS risks $(19,21,22)$. Almost $90 \%$ of the AAS users use cycling pattern to avoid the harmful effects of AAS.

As has been reported by other studies, our study showed that the main reason for AAS use among the AAS users was muscle building $(77.53 \%)$ and this was statically significant $(\mathrm{P}<$ 0.001) (22).

In spite of these AAS are illegal in Saudi Arabia, our participants got these substances by illegal ways. in our survey, the main source was the gym coaches $(55.06 \%)$ followed by online shopping $(16.85 \%)$. The main source was inconsistent between studies. for example, some studies reported similar finding as our study (the gym trainers were the main source of AAS) $(19,3)$, while other studies showed the online shopping was the main source (20).

In our survey, majority of users (68.54\%), used both oral and injectable AAS forms similar to Kuwait study (3). The most commonly used oral AAS form was; oxandrolone(61.80\%) while the most commonly used injectable AAS were Metenolone enanthate (50.56\%). This was inconsistent between studies. Some studies found Testosterone was the commonly used AAS between users $(19,20)$.

The most commonly used substance for post cycle therapy was Tamoxifen citrate in $67.42 \%$ of the users followed by Human chorionic gonadotropin-HCG (pregnyl) in $57.30 \%$ of the users. Substances used in the cycling pattern was not mentioned by other middle east studies.

Almost all AAS users (96.63\%) used other hormones, followed by proteins (85.39\%) in addition to AAS. Althobiti study reported that the most commonly used other substances were multivitamin/mineral supplements $(19,20)$.

We have some limitations in our study. Females were not included since it is difficult to reach them with the fact that there were no female gyms at the time of the study. Since the use of these substances is illegal, we expect that the AAS use may be underestimated due to self-underreporting. In spite of our study was meant to study the knowledge of the participants, our questionnaires were lacking detailed harmful effects of these substances. I believe that the fact that our study includes AAS patterns used and the types of post cycling therapy considered to be a strength point in our study.

\section{CONCLUSION}

Our study reported lower prevalence of AAS among gymnasts in the eastern province in comparison with other studies in Saudi Arabia. This could be due to self underreporting of AAS use. Gym coaches were the main source for AAS. In our study, the gym users have inadequate knowledge about AAS and its harmful effects. Oxandrolone was the most commonly used oral AAS. Cycling pattern was the most pattern used by AAS users. The most commonly used substance for post cycle therapy was Tamoxifen citrate.With the increasing numbers of AAS users, organized educational programs are needed to educate the public about the adverse effects of these substances. More restrict regulation are needed for the gyms and gym trainers.

\section{REFERENCES}

1. David A, David M, Samir A. Doping in sports and its spread to at-risk populations: an international review. World $\mathrm{J}$ Psychiatry. 2007;6(2):118-23.

2. Gary I, Brian H. Drugs and The Athlete. Philadelphia: F.A. Davis Co.; 1989.

3. Alsaeed I, Alabkal JR. Usage and perceptions of anabolic androgenic steroids among male fitness center attendees in Kuwait-a cross-sectional study. Subst Abuse Treat Prev Policy. 2015;10(1):33. https://doi.org/10.1186/s13011-0150030-5 PMid:26296560 PMCid:PMC4546264

4. Shehzad S, Justin T, Adrian D. Clinical review 138: Anabolicandrogenic steroid therapy in the treatment of chronic diseases. Int J Clin Endocrinol Metab. 2001;86(11):5108-17. https://doi.org/10.1210/jc.86.11.5108

5. Committee on Sports Medicine and Fitness. Adolescents and anabolic steroids: A subject review. Pediatrics. 1997;99(6): 904-8. https://doi.org/10.1542/peds.99.6.904

6. Trenton AJ, Currier GW. Behavioral manifestations of anabolic steroid use. CNS Drugs. 2005;19(7): 571-95. https://doi.org/10.2165/00023210-200519070-00002 PMid:15984895

7. Evans NA. Gym and tonic: A profile of 100 male steroid users. $\mathrm{Br} J$ Sports Med. 1997;31(1):54-8. https://doi.org/10.1136/bjsm.31.1.54 PMid:9132214 PMCid:PMC1332477

8. Wilson, J.D. Androgen Abuse by Athletes. Endocrine Reviews. 1988;9:181-99. https://doi.org/10.1210/edrv-9-2181 PMid:3042375

9. Brower KJ, Blow FC, Young JP, Hill EM. Symptoms and correlates of anabolic-androgenic steroid dependence. $\mathrm{Br}$ J Addict. 1991;86(6):759-68. https://doi.org/10.1111/j.13600443.1991.tb03101.x PMid:1878625

10. Harry R, Sara O, Ed D. Anabolic androgenic steroids: what the psychiatrist needs to know. Advances in Psychiatric Treatment. 2007;13:203-11. https://doi.org/10.1192/apt. bp. 105.000935

11. Bolding, Sherr L, Elford J. Use of anabolic steroids and associated health risks among gay men attending London gyms. Addiction. 2002;97(2):195-203. https://doi.org/ 10.1046/j.1360-0443.2002.00031.x PMid:11860391

12. Van Amsterdam J, Opperhuizen A, Hartgens F. Adverse health effects of anabolic-androgenic steroids. Regul Toxicol Pharmacol. 2010;57(1):117-23. https://doi.org/ 10.1016/j.yrtph.2010.02.001 PMid:20153798

13. Kutscher EC, Lund BC, Perry PJ. Anabolic steroids: a review for the clinician. Sports Med. 2002;32(5):285-96. https://doi.org/10.2165/00007256-200232050-00001 PMid:11929356

14. Schroeder ET, Singh A, Bhasin S, et al. Effects of an oral androgen on muscle and metabolism in older, communitydwelling men. Am J Physiol Endocrinol Metab. 2003;284(1):E120-8. https://doi.org/10.1152/ajpendo. 00363.2002 PMid: 12388137

15. Pope HG Jr, Kouri EM, Hudson Jl. Effects of supraphysiologic doses of testosterone on mood and aggression in normal men: a randomized controlled trial. Arch Gen Psychiatry. 2000;57(2):133-40. https://doi.org/10.1001/archpsyc.57.2.133 PMid:10665615 
16. Bhasin S, Storer T, Berman N, et al. Testosterone Replacement Increases Fat-Free Mass and Muscle Size in Hypogonadal Men. J Clin Endocrinol Metab. 1997;82:40713. https://doi.org/10.1210/jcem.82.2.3733 PMid:9024227

17. Bhasin S, Woodhouse L, Casaburi R, et al.Testosterone dose-response relationships in healthy young men. Am J Physiol Endocrinol Metab. 2001;281:E1172-E1181. https://doi.org/10.1152/ajpendo.2001.281.6.E1172

PMid:11701431

18. Sattler FR, Schroeder ET, Dube MP, et al. Metabolic effects of nandrolone decanoate and resistance training in men with HIV. Am J Physiol Endocrinol Metab. 2002;283:E1214 E1222. https://doi.org/10.1152/ajpendo.00189.2002 PMid:12388173

19. Althobiti SD, Alqurashi NM, Alotaibi AS, Alharthi TF, Alswat KA. Prevalence, Attitude, Knowledge, and Practice of Anabolic Androgenic Steroid (AAS) Use Among Gym Participants. Mater Sociomed. 2018;30(1):49-52. https://doi.org/10.5455/msm.2018.30.49-52

PMid:29670477 PMCid:PMC5857039
20. AlBishi K, Afify A. Prevalence and awareness of Anabolic Androgenic Steroids (AAS) among gymnasts in the western province of Riyadh, Saudi Arabia. Electron Physician. 2017;9(12):6050-7. https://doi.org/10.19082/6050 PMid:29560159 PMCid:PMC5843433

21. Tahtamouni LH, Mustafa NH, Alfaouri AA, Hassan IM, Abdalla MY, Yasin SR. Prevalence and risk factors for anabolic-androgenic steroid abuse among Jordanian collegiate students and athletes. The European Jour-nal of Public Health. 2008;18(6):661-5. https://doi.org/10.1093/ eurpub/ckn062 PMid:18603598

22. Al-Falasi O, Al-Dahmani K, Al-Eisaei K, et al. Knowledge, attitude and practice of anabolic steroids use among gym users in Al-Ain District, United Arab Emirates. Open Sports Med J. 2008;2:75-81. https://doi.org/10.2174/18743870008 02010075

23. Al Ghobain M, Konbaz MS, Almassad A, et al. Prevalence, knowledge and attitude of prohibited substances use (doping) among Saudi sport players. Substance Abuse Treatment, Prevention, and Policy. 2016;11:14. https://doi.org/10.1186/s13011-016-0058-1 PMid:27083557 PMCid:PMC4833935 